\title{
KONUT KAPICILARININ ÇALIŞMA HAYATI: AĞRI İLİ ÖRNEĞ́̇
}

\author{
$\underline{\text { Hayrettin Șahin }}^{1}$
}

1ORCID ID: http://orcid.org/0000-0001-8921-2840

Öz

Kentleşmenin artması ile özellikle çok katlı binalarda ortak işlerin yapılması için konut kapıcıların çalıștırılması yaygınlaşmıștır. Bu meslek zamanla kentlerin bütününe yayılmıștır. Konut kapıcılarının sayısındaki artış beraberinde hukuki düzenlemeleri de getirmiştir. Araştırmanın amacı, Ağrı ili Merkez ilçesinde, konut kapıcısı olarak çalışanların görev ve haklarını süreç içerisinde ele almak ve karşılaştıkları sorunları tespit etmektir. Araştırmanın verileri katılımcı gözlem yöntemi kullanılarak toplanmıştır. Araştırma sırasında gözlemlenen dokuz konut kapıcısı, iki apartman yöneticisi ve üç atık kömür toplayıcısı bulunmaktadır. Araştırma sonucunda, konut kapıcıları iş bulurken akraba ve hemşerilerinden yardım aldıkları, sözlü sözleșme ile ișe başladıkları, ișten ayrılırken fesih süreleri ve tazminatları dikkate alınmadığı görülmüsstür. Konut kapıcılarının aldığı ücret asgari ücret seviyesindedir. Çalışma saatleri bazı dönemlerde çok yoğunlaşsa da yılın tümü göz önüne alındığında haftalık kırk beş saatin altında kaldığı söylenebilir. Konut kapıcılarının çoğu kapıcı konutundan yararlanamamaktadır. Kayıtsız çalıştıklarından dolayı primli sosyal güvenlik kollarından faydalanamamaktadırlar. Diğer taraftan konut kapıcıları atık kömür toplayıcılarını çalıștırarak, ev kiralayanlardan komisyon alarak ve kurye işleri yaparak ek menfaat elde ettikleri görülmüş̧ür.

Anahtar Kelimeler: Çalışma Sosyolojisi, Çalışma Hayatı, Konut Kapıcıları, İş Hukuku, Atık Kömür Toplayıcları

Atıf için:

Şahin, H. (2021). Konut kapıcılarının çalışma hayatı: Ağrı ili örneği. HAK-IŞ Uluslararası Emek ve Toplum Dergisi, 10(27), 299-319.

\footnotetext{
${ }^{1}$ Dr. Öğr. Üyesi., Sinop Üniversitesi, Boyabat IïBF, Sinop/Türkiye

E-posta: sahinhayrettin@gmail.com
} 


\title{
WORKING LIFE OF HOUSE JANITORS: THE CASE OF AĞRI PROVINCE
}

\begin{abstract}
With the increase of urbanization, it is common to employ janitors to carry out common works especially in multi-storey buildings. This profession spread over the other cities in time. The increase in the number of janitors brought with it legal regulations. The aim of the study is to examine the duties and rights and to identify the problems they encounter of those who work as a house janitors in Ağrı province Central district. The data of the research were collected by using participant observation method. There are nine house janitors, two apartment managers and three waste coal collectors observed during the survey. As a result of the research, it was seen that the house janitors were getting help from their relatives and fellow countrymen while finding a job, started with a verbal contract, termination periods and compensation are not taken into account when leaving the job. The wage received by house janitors is at the level of minimum wage. Although the working hours are very busy at some periods, it can be said that it remains under forty-five hours per week when the whole year is considered. Most of the house janitors cannot benefit from the concierge flat. They cannot benefit from premium social security branches due to unregistered employment. On the other hand it has been observed that house janitors gain additional benefits by hiring waste coal collectors, taking commission from renters and doing courier work.
\end{abstract}

Keywords: Labor Sociology, Working Life, House Janitors, Labor Law, Waste Coal Collectors 


\section{GİRIŞ}

Kapıcıların, geleneksel dönemde genelde varlıklı ailelerin evinde ve kamu kurumu denilebilecek yerlerde çalıştığı bilinmektedir. Görevleri bakımından bugün yaptıklarından oldukça farklı şekilde çalışmaktadırlar. Bazıları sadece bir noktada bekçi görevi yaparken, bazıları özel kalem ve kurye işleri yaptıkları idare tarihi kitaplarında görülmektedir. Modern dönemde, hızlı kentleşmenin sonucunda konut kapıcılığı mesleği yaygınlaşmış ve önem kazanmıştır. Bu durumda, konut kapıcılığı mesleğinin iki önemli işlevi söz konusudur. Kırdan gelen göçmenlere iş sağlamak ve kırdan geldiği için kente uygun olmayan işgücünün ${ }^{2}$ işgücü piyasasına girmesinde rol almaktır.

Kırdan göç edenler kentte tutunabilmek için ilk etapta niteliği düşük çeşitli işlere girmektedirler. İnşaat, temizlik, kapıcılık ve çocuk bakıcıllğı işleri bu işlerin başında gelmektedir. İnşaat ve kapıcılık işlerinde genelde erkekler çalışırken temizlik işlerinde ve çocuk bakıcılığında kadınlar çalışmaktadır. Konut kapıcılarının başlıca görev ve sorumlulukları Konut Kapıcıları Yönetmeliği'nde sekiz madde halinde düzenlenmiştir. Ancak araştırmanın yapıldığı yörede konut kapıcılarının üç temel görev ve sorumluğunun bulunduğu tespit edilmiştir. Bunlar, kalorifer kazanını ateşlemek, çöpleri toplamak, apartman ortak alanlarını temizlemektir.

Konut kapıcılarının görevleri, doğalgazın konut ısıtmasında kullanılmasıyla önemli ölçüde değişmiştir. Kalorifer kazanı ateşleme işi büyük oranda azalmıştır. Çöp toplama ve apartman ortak alanlarının temizlenmesi işleri ise artarak devam etmektedir. Kalorifer kazanı ateşleme işinin ortadan kalkması, konut kapıcılığında istihdam olanların cinsiyetinde de değişime neden olmuştur. Temizlik ve çöp toplama işlerinin kadınlara, güvenlik görevliliği işlerinin erkeklere verilmesine birçok kentte sıkça rastlanmaktadır.

Günlük bina temizliği, çöplerin toplanması, kalorifer ateşlemesi vb. işler iki saatlik zaman diliminde yapılabilmektedir. Bundan dolayı kapıcılık yapanlar çoğunlukla üç, bazen dört ayrı binanın görev ve sorumluluğunu üstlenmektedir. İşlerinin artması ile gelirleri de artmaktadır. Gelir durumları bakımından yoksulluk sınırında olsalar da bulundukları bölgenin gelir durumu göz önüne alındığında orta sınıfa yakın sosyal hayat standardını yakalamış bulunmaktadırlar.

\footnotetext{
2 Kırdan göç edenlerin nitelikleri modern toplumun çalışma hayatına uygun olmadığı söylenebilir. Ama niteliksiz olduklarını varsaymak doğru değildir. Tarım ve hayvancılığın kendine has ince bilgileri bulunmaktadır. Tarım ve hayvancılık işlerinin kentteki işlerden daha zor olduğu bilinmektedir. Köyden kente göç edenler bu durumdan sık sık bahsetmektedirler. Çünkü hayvanın yönetilmesi makinenin yönetilmesinden, gıda ürünlerin elde edilmesi de sanayi ürünlerinin elde edilmesinden daha karmaşık ve zordur. Hepsinden önemlisi tarım ürünleri ve hayvan iklim koşullarından oldukça fazla etkilenmektedir. Kırdan kente göç edenlerin niteliksiz olduklarından değil niteliklerinin kente uygun olmadığından bahsedilebilir.
} 
Kapıcıların iş bulmalarında ağ ilişkileri çok önemlidir. Gerek erkek gerekse kadın olsun işe yerleşebilmesi için genelde ağ ilişkilerini kullanmaktadır. İş bulmak için kullanılan ağ ilişkilerinde, işe ilk girişte akraba ve hemşerileri sonraki süreçte ise, genelde iş arkadaşları ilk sırayı almaktadır. Konut kapıcılarının ücret hesaplama biçimleri genelde götürü ücret yöntemi ile yapılmaktadır. Konut kapıcısının işi bir saatte ya da yarım saatte yapmasının bir önemi yoktur. 0 işin yapılmış olması önemlidir.

Araştırma, etnografik yaklaşım temel alınarak yapılmıştır. Etnografik yaklaşım, kültürel bağlamı içinde bireyleri gözlemleyerek rutini kendi doğal çevreleri içinde anlamayı amaçlamaktadır (Bates, 2013, s.11). Bu yaklaşımda kullanılan yöntemlerden her birisi gözden geçirilmiştir. Araştırmanın hangi araştırma tekniği ile yapılmasının daha faydalı olacağına yönelik analizler yapılmıştır. Araştırılan konu ve kişi bakımından anket, mülakat ve gözlem teknikleri değerlendirilmiştir. Katılımcıların eğitim düzeylerinin düşük olması, anket araştırma tekniğinin araştırmada olumlu sonuç vermeyeceği kanaati olușturmuştur. Diğer yandan mülakat yaparken kullanılması gereken aletlerin katılımcıların ifadelerini oldukça etkilediği görülmüştür. Özellikle 2015 yılı sonrasında oluşan siyasi kamplaşmanın kişilerin davranışlarında önemli tesirleri, mülakat tekniği ile araştırma yapmayı zorlaştırmıştır. Katılımcıların seslerinin kaydedilmesi olanaksız hale gelmiştir. Her ne kadar kişilerin ses kaydı yapılmamış olsa da onlara konu ile ilgili sorular sorulmuştur. Bu sorulara verilen cevaplar kaydedilmediği için araştırmada mülakat yapıldığı belirtilmemiştir. Araştırmacının araştırma yapılan yerde yaşaması ve konut kapıcılarını sürekli görebilmesi, gözlem yönteminin bu araştırma için uygun olabileceği kanaatini sağlamıştır.

Bu çalışma, Ağrı ilinde gerçekleştirilen uzun dönemli katılımcı gözlem sonucuna dayanmaktadır. Araştırmanın karar verildiği 2015 yılından araştırmanın yayına hazırlandığı 2020 yılına kadar gözlemler sürdürülmüştür. Araştırmada Ağrı ili Merkez ilçesinde konut kapıcısı olarak çalışan erkekler ele alınmıştır. Konut kapıcılarının çoğu kayıtsız çalıştığı için evren sayısını ortaya çıkarmak olanaksız gözükmektedir. Evrendeki konut kapıcılarının sayısı konutların sayısı temel alınarak hesaplanmaya çalışılmıştır. Ama konutların kaç katlı olduğu kayıtlarda gösterilmediği için hesaplamada başarı sağlanamamıștır. Evren ve örneklem hesaplamanın zorluğunun yanı sıra konut kapıcılarının çalıştığı belirli bir mekânlarının olmaması onlarla iletişime geçmeyi de güçleştirmektedir. Tüm bu şartlar altında araştırmacı ulaşabildiği kişiler üzerinden araştırmasını yapabilmiştir.

Katılımcıların sayısı şu şekildedir: Konut kapıcılarından 9 kişi, atık toplayıcılardan 3 kişi ve apartman yöneticilerinden 2 kişidir. 
Tablo 1. Katılımcılar- Konut Kapıcısı

\begin{tabular}{|c|c|c|c|c|c|}
\hline 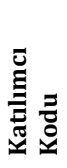 & $\stackrel{\bar{\pi}}{\pi}$ & 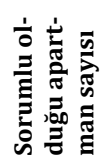 & 离 & : & 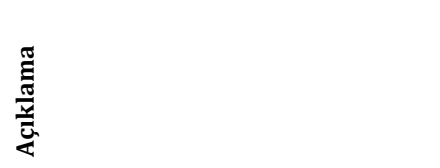 \\
\hline K1 & 28 & 3 & 3 & $\begin{array}{l}\text { Temizlik, kalorifer ka- } \\
\text { zanını ateşleme ve } \\
\text { çöpleri taşıma }\end{array}$ & $\begin{array}{l}\text { Kendi evinde oturuyor. İşyerine her } \\
\text { gün gidip geliyor. Evi işyerinden yakla- } \\
\text { şlk } 5 \mathrm{~km} \text { uzakta. Abide mahallesi. }\end{array}$ \\
\hline K2 & 33 & 3 & 4 & $\begin{array}{l}\text { Temizlik, kalorifer ka- } \\
\text { zanını ateşleme ve } \\
\text { çöpleri taşıma }\end{array}$ & $\begin{array}{l}\text { Kapıcı konutunda oturuyor. Sigorta } \\
\text { primleri ödeniyor. Firat mahallesi. }\end{array}$ \\
\hline K3 & 45 & 4 & 6 & $\begin{array}{l}\text { Temizlik, kalorifer ka- } \\
\text { zanını ateşleme ve } \\
\text { çöpleri taşıma }\end{array}$ & $\begin{array}{l}\text { Kapıcı konutunda oturuyor. Aynı Ma- } \\
\text { hallede dört ayrı binadan sorumludur. } \\
\text { Binaların birbirine uzaklığı yaklaşı } \\
200 \text { metre civarındadır. Primini ken- } \\
\text { disi ödüyor. Abide Mahallesi. }\end{array}$ \\
\hline K4 & 42 & 3 & 5 & $\begin{array}{l}\text { Temizlik, kalorifer ka- } \\
\text { zanını ateşleme ve } \\
\text { çöpleri taşıma }\end{array}$ & $\begin{array}{l}\text { Kendi evinde oturuyor. Atık kömür } \\
\text { toplayıcılarına kömür verdiği gerekçe- } \\
\text { siyle bir binanın sorumluluğundan ç- } \\
\text { karılmıştır. Fırat Mahallesi. }\end{array}$ \\
\hline K5 & 50 & 4 & 2 & $\begin{array}{l}\text { Temizlik, kalorifer ka- } \\
\text { zanını ateşleme ve } \\
\text { çöpleri taşıma }\end{array}$ & $\begin{array}{l}\text { Kendi evinde oturuyor. Sorumlu ol- } \\
\text { duğu binalar birbirine yakın. Fırat Ma- } \\
\text { hallesi. }\end{array}$ \\
\hline K6 & 35 & 2 & 3 & $\begin{array}{l}\text { Temizlik, kalorifer ka- } \\
\text { zanını ateşleme ve } \\
\text { çöpleri taşıma }\end{array}$ & $\begin{array}{l}\text { Kendi evinde oturuyor. Sorumlu ol- } \\
\text { duğu binalar birbirine uzakta. Fevzi } \\
\text { Çakmak Mahallesi ve Firat Mahallesi. }\end{array}$ \\
\hline K7 & 42 & 3 & 4 & $\begin{array}{l}\text { Temizlik, kalorifer ka- } \\
\text { zanını ateşleme ve } \\
\text { çöpleri taşıma }\end{array}$ & $\begin{array}{l}\text { Kapıcı konutunda oturuyor. Sorumlu } \\
\text { olduğu binalar yakın. Firat Mahallesi. }\end{array}$ \\
\hline K8 & 35 & 3 & 5 & Temizlik & Kendi evinde oturuyor. \\
\hline K9 & 41 & 3 & 6 & $\begin{array}{l}\text { Kalorifer kazanını } \\
\text { ateşleme }\end{array}$ & Kendi evinde oturuyor. \\
\hline
\end{tabular}

Tablo 2. Katılımcılar- Apartman Yöneticisi

\begin{tabular}{lllll}
\hline $\begin{array}{l}\text { Katılımcı } \\
\text { Kodu }\end{array}$ & Yaşı & Medeni Durumu & $\begin{array}{l}\text { Apartmandaki } \\
\text { Sayısı }\end{array}$ & Daire \\
\hline K10 & 61 & Evli & 14 & 3 \\
K11 & 47 & Evli & 24 & 4 \\
\hline
\end{tabular}

Tablo 3. Katılımcılar- Atık Kömür Toplayıcısı

\begin{tabular}{llll}
\hline Katılımcı Kodu & Yaşı & Medeni durumu & Ailedeki kişi sayısı \\
\hline K12 & 13 & Bekâr & 6 \\
K13 & 14 & Bekâr & 7 \\
K14 & 25 & Bekâr & 5 \\
\hline
\end{tabular}

\section{Konut Kapıcılığı Mesleği}

Türk Dil Kurumu kapıcı kelimesini iki ayrı maddede tanımlamaktadır. Birincisi; Otel, apartman vb. büyük yapılarda bekçilik, temizlik, alışveriş gibi işlerle görevli kimseye denilir. İkincisi ise, Osmanlı Devlet Teşkilatı'nda saray kapılarını bekleyen görevli sınıfına denilmektedir.

Konut Kapıcıları Yönetmeliği'nin üçüncü maddesine göre, konut kapıcısı: Anataşınmazın bakımı, korunması, küçük çaptaki onarımı, ortak yerlerin ve 
döşemelerin bakımı, temizliği, bağımsız bölümlerde oturanların çarşı işlerinin görülmesi, güvenliklerinin sağlanması, kaloriferin yakılması ve bahçenin düzenlenmesi ve bakımı ve benzeri hizmetleri gören kişidir.

Geleneksel dönemin kentlerinde kapıcllık veya bekçilik çarşılarda, medreselerde, saraylarda, külliyelerde vb. yerlerde görülmektedir (Ünal , 2019, s. 65). Köylerde ise suyun sırasını belirlemek için bekçi, arazinin korunması için korucu (korukçu) bulunmaktadır (Şahin, 2019, s. 10).

Kapıcllık mesleğini organizasyonla bağdaştırarak ifade etmek belki daha açıklayıcı olabilir. Belirli bir organizasyonun ilk müracaat edileni ya da bu organizasyonların elinde çalıştırılan kişi anlamlarına gelmektedir. Bu anlamda, kapıcılık görevinin eski dönemlerden beri var olan bir meslek olduğu söylenebilir.

Uzmanlaşma, iş bölümü, kentlerin nüfusunun artması, inşaat teknolojisinin gelişmesi ve kentlerde taşınmazların değerlerinin yükselmesi ile insanların müstakil konut yerine toplu konutlara yönelmesi sonucunda kapıcılık mesleği yaygınlaşmaya başlamıştır.

Çok katlı binaların getirmiş olduğu maliyet düşüklüğü her apartmanda kapıcı çalıştırmayı mümkün kılmıştır (Yola, 2017). Çünkü orta gelir durumunda bir kişinin müstakil konutta, konut kapıcısı çalıştırması oldukça maliyetli görünmektedir.

Özellikle 2000'li yıllarla birlikte Türkiye'de doğalgazın yaygınlaşması ve inşaat yapmanın maliyetinin düşmesi aynı zamanda zenginleşme ile gelen tatmin olma düzeylerinin değişmesi konutlara yansımaya bașlamıştır. Bu değişimle, kapıcıların görevlerinde farklılıklar olmuștur. Bir dönem, konut kapıcılarının ağırlıklı görevi olan kalorifer kazanı ateşleme görevi yerini temizlik, bekçilik ve kurye işlerine bırakmaktadır.

Konut kapıcılığının yaygınlaştığı tarih ile bu konunun İş Kanuna yansıması paralellik arz etmektedir. 1936 yılında kabul edilen İş Kanunu'nda kapıcılıkla ilgili herhangi bir düzenlemeye rastlanmazken sonraki yıllarda bununla ilgili düzenlemeler görülebilmektedir. 1971'de yürürlüğe konan 1475 sayılı İş Kanunu ile Konut Kapıcıları ve Kapıcılık Hizmetleri, kısmen ve bazı şartlarla İş Kanunu kapsamına ilk defa alınmıştır (Okay, 1979, s. 42). Uygulanmakta olan 4857 sayılı İş Kanunun 110. Maddesine göre; "Konut kapıcılarının hizmetlerinin kapsam ve niteliği ile çalışma süreleri, hafta tatili, ulusal bayram ve genel tatil günleri, yıllık ücretli izin hakları ve kapıcı konutları ile ilgili hususların düzenlenmesinde uygulanacak değişik şekil ve esaslar Çalışma ve Sosyal Güvenlik Bakanlığı'nca (Aile, Çalışma ve Sosyal Hizmetler Bakanlığı) hazırlanacak bir yönetmelikle düzenlenir" denilmektedir.

Konut Kapıcıları Yönetmeliği, 25391 sayılı Resmi Gazete 'de 3 Mart 2004 tarihinde yayınlanmıştır. Bu yönetmeliğe göre konut kapıcılarının çalışma hayatı düzenlenmektedir. Bu maddelerden gerekli görülenler ilgili bölümlerde verilmiş ve araştırma kapsamında değerlendirmeler yapılmıştır. 
Yönetmeliğin 5. maddesine göre, konut kapıcısının görev ve sorumlulukları şunlardır:

a) Yöneticinin talimatı doğrultusunda konutun kaloriferini zamanında yakmak ısıyı ayarlamak ve söndürmek,

b) Hidrofor ve benzeri araçları çalıştırmak,

c) Anataşınmazın ortak yerlerini ve tesislerini temiz bulundurmak, demirbaşlarını, araç ve gereçlerini, düzenli, bakımlı ve işler şekilde tutmak,

d) Kendisine ayrılan konutu başka amaçlarla kullanmamak, konutu korumak, kendisi veya ailesinden birisinin konuta vereceği zarar ve hasarları karşılamak,

e) Yöneticinin talimatı çerçevesinde konutun güvenliğini sağlayıcı önlemleri almak,

f) Belirlenen saatlerde servis hizmetlerini görmek, çöpleri toplamak, bahçe düzenlemesi ve bakımını yapmak,

g) Verilen eğitimlere uygun davranmak ve koruyucu malzemeyi kullanmak,

h) İş veya toplu iş sözleşmesinde belirlenen diğer görevleri yerine getirmektir.

Ağrı ilinde çalışan kapıcıların iş tanımında, iş tasnifi yapılacak olursa, kapıcıların üç çeşit iş yaptıkları söylenebilir. Bunlar; apartmanın ortak alanlarının temizliğini yapmak, çöplerini toplamak ve kalorifer kazanını ateşlemektir. Bazı konut kapıcıları sadece temizlik işi yaparken bazı konut kapıcıları da sadece ateşleme işi yapmaktadırlar. Ancak her üç görevi aynı anda yapan konut kapıcılarının sayısı fazladır. Görevlerin farklı iki kişiye verilmesi, genelde az katlı apartmanlarda görülmektedir. Apartman yöneticisi üç işi ayırarak yıllık konut kapıcısı çalıştırma maliyetini düşürmektedir. Apartman yöneticisi, temizlik iși yapan kiși ile haftalık bir kez apartmanın ortak alanlarını temizlemesi karşılığında anlaşmaktadır. Diğer yandan kalorifer kazanı ateşleyen kişi ile sezonluk anlaşma yapılmaktadır. Yaklaşık dört ya da beş ay kalorifer ateşleyicisine ücret vermeyerek tasarruf etmektedir. Apartmandaki çöplerin çöp konteynırına atılması işi ise apartman sakinleri tarafından bizzat yerine getirilmektedir (K1, K2, K3, K4, K5, K6, K7, K8, K9).

Kalorifer kazan ateşleyicileri genelde erkeklerden oluşurken apartman temizleyicilerinin birçoğu kadınlardan oluşmaktadır. Doğalgazın binaların ısıtılmasında kullanılması sonucunda erkeklerin kurye ve bekçilik işleri yaptığı görülmektedir. Kadınlar ise temizlik işlerini yapmaktadır.

Konut kapıcıları yaptıkları işin karşılığı olarak ücret, izin, konut ve sosyal güvenlik hakları bulunmaktadır. Ağrı'da çalışan konut kapıcılarının çalışma hakları bakımından durumları oldukça kritik görülmektedir. Araştırmada bu hakların ne kadarının sağlandığı ile ilgili ayrıntılar mevcuttur.

\section{Katılımcıların Sosyoekonomik Profili}


Türkiye İstatistik Kurumu 2020 verilerine göre Ağrı ilinin, il ve ilçe merkezlerinde 310896 kişi, belde ve köylerinde 224539 kişi bulunmaktadır. Kentte doğum oranları yüksek olmasına karşın sürekli dışarıya göç vermesinden kaynaklı nüfus azalışı görülmektedir. Bu azalış, 2018 yılı hariç, 2011 yılından beri devam etmektedir.

Ağrı ilinde hane halkı sayısında ve doğum oranlarında azalma (Uğurlu \& Genç, 2018, s. 303), konut sayılarında yükseliş söz konusudur (Turan vd. 2018, s. 15). Bu istatistikler modern toplumların özellikleri ile benzerlik göstermektedir.

Ağrı ili yaşam endeksi gösterge değerlerinin geneli Türkiye ortalamasının altında kalmaktadır. En belirgin farklar konut, gelir ve servet değerlerinde görülmektedir. Ağrı ilinde gerek sermaye birikiminin az olması gerekse kişi başına düşen gelir seviyesinin düşük kalması (Kılıç \& Beşer, 2018, s. 150) kentin her tarafında kendini göstermektedir. Altyapı, istihdam, ulaşım, ticaret, üretim vb. veriler bu durumu açıkça göstermektedir.

Ağrı ilinde istihdam edilenlerin oranı yüksek görünmektedir. Bunun nedeni iş başvurusunda bulunmamaktan kaynaklı olabilir. Ağrı'da iş bulma umudu olmayanlar genelde Türkiye'nin batısında bulunan büyükşehirlere iş bulmak için göç etmektedirler. Göç verilerinde bu bariz şekilde görülmektedir.

Ağrı ilinin batı tarafı memurların ve gelir durumu yüksek olanların yaşadığı yerdir. Özellikle Abide ve Fırat Mahallesinin olduğu yörede çok katlı binalar yoğun olarak bulunmaktadır. Bu binalarda çeşitli şekillerde çalıştırılan insanlar görülmektedir. En fazla görülen çalıștırılma şekli konut kapıcılığı, çocuk bakımı ve temizlik işleridir. Diğer yandan bu apartmanların atık kömürlerinden geçimini sağlayan atık toplayıcıları da bulunmaktadır.

Katılımcıların, yaşı genelde orta yaşlarda (30-50) yoğunlaşmaktadır. Çoğu evlidir. Gelir durumları yoksulluk sınırındadır. Eğitim durumları ise, çoğunlukla okuryazar, ilköğretim ve ortaöğretim düzeyindedir (K1, K2, K3, K4, K5, K6, K7, K8, K9).

Okula gitmeyen kişiler genelde on beş yaşında işe başlamaktadır. On beş ile otuz yaş arasında çok çalışarak ailenin statüsünü değiştirme çabası içerisinde olmaktadırlar. Özellikle kırklı yaşlara gelinceye kadar sınıf değiştirme olanakları bulunmaktadır. Baba olduğu dönemde sınıf değiștiremeyenler, dede olduğu dönemde çocuklarının ve torunlarının çabaları ile sınıf değiştirdiği görülmektedir (K1, K2, K3, K4, K5, K6, K7, K8, K9, K10, K11).

Katılımcılar arasında evlilik oranı yüksektir. Evlilik oranları çok yüksek olsa da evlilik yaşı değişmektedir. Evlilik yaşları yükselmektedir. Geleneksel dönemde on yedi yaşında evlenilirken bu durumda yirmi beş ve otuz yaş arası normal sayılmaktadır (K1, K2, K3, K4, K5, K6, K7, K8, K9, K10, K11, K13, K14). 
Geleneksel dönemde evli olanların verdiği güven modern dönemde de devam etmektedir. Kişiyi bağlayan en önemli bağın aile olduğu düşünülmektedir. Bu bağdan dolayı kişilerin suç işlemeye meylinin azalacă̆ varsayılmaktadır. Sorumluluğu arttığı için davranışlarını düzelteceği öngörülmektedir (K3, K5, K9, K10, K11).

Katılımcıların, neredeyse hepsi Ağrı ilinde doğmuşlardır. Bir kısmı ilçelerinden bir kısmı da köylerindendir. Kırsal kesimin oranı fazladır. Çoğunun anne babası çiftçi ve köylüdür. Yakın çevreden göç ederek gelmişlerdir (K1, K2, K3, K4, K5, K6, K7, K8, K9, K10, K11, K12, K13, K14).

Konut kapıcılarını kentte kalmaya ve düşük ücretli işlerde çalışmaya motive eden neden çocuklarının kentte iyi bir eğitim alması, orta sınıf düzeyinde bir işe yerleşmesi ve sağlık kurumlarından kolayca yararlanabilmesidir. Bunlar dışından birçok neden de sayılabilir ancak görüşmeler neticesinde bu nedenler çok dile getirilmektedir. Konut kapıcısı olarak çalışanlar kendilerinden ziyade çocukları için kentte yaşadıklarını belirtmektedir (K4, K5, K6, K8, K9, K10, K11).

Kente göç etmek köylüler için bir amaç halini almıştır. Köyden kente göç edenler köy toplumu tarafından ödüllendirilmektedir. Kente göç edenler saygınlık kazanmakta, evlenmeleri kolaylaşmaktadır. Kente göç etmeyenler hakir görülmektedir. Köylülük kentliliğin altında bir sınıf olarak algılanmakta$\operatorname{dir}(\mathrm{K} 4, \mathrm{~K} 5, \mathrm{~K} 6, \mathrm{~K} 7)$.

Kente göç edenlerin bir dönem sonra kazançları artmaktadır (K1, K2, K3, K4, K5, K6, K7, K8, K9, K10, K11). Köydeki durumdan farklı olarak, ellerine para geçmekte ve paranın sağladığı alım gücü psikolojik olarak onları motive etmektedir.

Kente göç esnasında, göçmenlere hemşerileri önemli katkı sağlarken ileri süreçte kentte kurduğu ağ ilişkileri ön plana çımaktadır. Gelmiş olduğu köyün kültüründen ve çevresinden kısmen ayrılarak kentli olmaya başlamaktadır. Dayanışmanın yerini kısmen bireyin kendi ayakları üzerinde durması almaktadır. Diğer yandan da kentte kurmuş olduğu sosyal ağlar vasıtasıyla birçok ihtiyacını giderebilmektedir. Bu sosyal ağlar içerisinde komşuluk ilişkileri önemli yere sahiptir (K1, K2, K3, K4, K5, K6, K7, K8, K9, K10, K11, K12, K13, K14).

Kente yeni göç etmiş kapıcıların ekonomik durumu iyi değildir. Genelde kayıtsız olarak işe başlamaktadırlar. Sorumlu oldukları apartman sayısı azdır. Bu kişilerin zamanla daha yüksek ücretli, kayıtlı işlere doğru akımı görülmektedir. Kente göç edip konut kapıcısı olanlarda gözle görülür ekonomik iyileşme gözlemlenmiştir. İlk beş yıl içinde aile ve akrabalarına ekonomik yönden bağımlılı̆̆ı söz konusu iken, sonraki yıllarda araba aldıkları ve on yıldan sonra ev aldıkları gözlemlenmiştir. Diğer yandan çocuklarını da kentin gereklerine göre yetiștirdikleri söylenebilir (K4, K5, K7, K8, K9, K10).

Konut kapıcılarının düşük ücretle çalıştırıldığı söylenebilir. Birçok binanın sorumluluğunu almış olsalar da aylık kazançları üç bin TL civarındadır. Kapıcı dairesinde ikamet edenler işe yakınlığı, kira giderinin olmaması, 
ısınma maliyetinin düşmesi, kapıcı konutunun kendi konutundan estetik yönünden daha iyi olması ve ev işlerinin kolaylaşması bakımından müreffeh hayat yaşadıkları söylenebilir (K1, K2, K3, K4, K5, K6, K7, K8, K9, K10, K11).

Ataerkil yaşam biçimi görülmektedir. Dışarıda genelde erkekler çalışmaktadır. Geleneksel yaşam biçiminde yaşarken kısmen modern toplumun yaşam tarzı da benimsenmektedir.

Konut kapıcılarının eşleri genelde dışarıda çalışmamaktadır. Aile içerisinde ev işlerini yapmaktadır. Ancak nadir olsa da konut kapıcısı eşlerinin kendi evinin dışında çalıştığına rastlanmıştır. Kapıcıların eşleri, ev dışında temizlik ve çocuk bakım işleri yapmaktadır.

Konut kapıcıları zamanla çalıștığı apartmanlardaki konutlarda ikamet eden birçok kişi ile samimi duruma gelmektedir. Kurulan bu güven ilişkisi, kadınların ev dışında işgücü piyasasına girmesine sebep olmaktadır. Eğer kişiler kendilerini güvende hissederse ev dışında çalışabilecekleri görülmektedir. Çalışan ve çalıștıranın güvenirliği referans yöntemleri ile olmaktadır. Özellikle kadınların günlük işlerde çalışması bu referans yöntemi ile gerçekleşmektedir ( K2, K3, K4, K6, K7, K9, K10, K11).

Ağrı ilinde, kadınların ev dışında çalışmaları gittikçe yaygınlaşmaktadır. Gerek ofis işleri, gerek temizlik ve çocuk bakım işleri, gerekse kamu görevleri olsun birçok işte kadınların çalıştığı görülmektedir.

Geleneksel yapıda, aile üyelerinin dışarda çalışması hoş karşılanmamaktadır. Aile kendi işlerini öncelemektedir. Ekonomik durumu iyi olmayanlar başkasına muhtaç olmaktansa başkasının işinde çalışmaktadırlar. Başkasının işinde çalışmada öncelik genç erkeklere tanınmaktadır (K1, K2, K3, K4, K5, K6, K7, K8, K9).

Konut kapıcılarının geldiği köylerde yapılan araştırmalar neticesinde, işi iyi olanlar değil, işi yolunda gitmeyenler daha çok dışarıda çalışmaktadır. Asıl olan kendi işini yapmaktır ve en önemlisi de kendi kendine yeter olmaktır. Kendi kendine yeter olabilmek için de kır toplumlarında çeşitli işler yapılmakta ve uzmanlaşmaya gidilmemektedir. Uğraş alanları çok çeşitlilik arz etmektedir. Alışverişten uzak durmaktadırlar ve tükettikleri malların kendilerinin üretmiş olmasına özen göstermektedirler.

Geleneksel yapıda, kadınların başkasının işinde çalışması, en son kabul edilecek durumdur. Çünkü aile kadın üzerine kurguludur. Kültürün ve geleneğin birinci dereceden aktarıcısı kadınların, gelenekten kopması ailenin tümden gelenekten kopacağı anlamına gelmektedir. Diğer yandan, kadının başkasının işinde çalışması aile içerisinde bulunun aile işletmeciliği ilkelerine de ters düşmektedir. Kişilerin dışarıda çalışması ile aile içerisinde bulunan çalışma düzeni bozulmaktadır. Bu bozulma bireyi özgür kılarken, aile işletmesini ortadan kaldırmaktadır. Kadının dışarda çalışmasının istenmemesinin altında yatan neden, güvenlikten ve aile işletmesini bir arada tutmaktan kaynaklanabilir. 
Kent ve köy arasındaki ilişkiler pergel ayaklı dönüşümle izah edilebilir. Baba ocağı-ana kucağı pergelin sabit tarafıdır. Ailenin boş kalan (işsiz) ve dışa dönük güçlü olan üyeleri ilk etapta pergelin hareketli ayağı gibi önce yakın yerleri sonra uzak yerleri yoklamaktadır. Daha iyi fırsat gördügü yerde bir yuvalanmaya girmekte ve ailede belirli kişileri planlı bir şekilde yanına çekmektedir. İkisi arasında (baba ocağında olan ve göç eden) sürekli bir iletişim hali bulunmaktadır. Zor durumda olan diğer taraftan sürekli desteklenmektedir. Modernleşme döneminde, bu iki taraf (pergelin ayakları) kırda ve kentte olmaktadır. Dönem dönem kırda yaşayan kenttekini, kentte yaşayan ise kırdakini desteklemektedir (K1, K2, K3, K4, K5, K6, K7, K8, K9, K10, K11, K12).

\section{4-Konut Kapıcılarının Çalışma Hayatının Değerlendirilmesi}

Konut kapıcıların çalışma hayatının değerlendirilmesi, kalorifer kazanı ateşleme, çöp toplama ve temizlik görevleri dikkate alınarak yapılmıştır. Kalorifer kazanı ateşleme görevi içerisinde kazanın temizlenmesi, küllerinin çöpe atılması, kömürün kazana doldurulması ve ateșleme sonrasında kontrollerin yapılmasını kapsamaktadır. Çöp toplama işi, konutların kapılarının önünde bulunan çöplerin alınıp çöp konteynırına götürülmesidir. Temizlik işi ise, haftada bir binanın ortak alanlarının temizliğinden oluşur. Apartmanlarda, merdivenler, apartman girişi, apartman giriş kapısı, asansör vb. yerler ortak alan olarak kabul edilmektedir.

Konut kapıcılarının çalışma hayatı, iş bulma, sözleşme yapma, işten ayrılma, ücret, çalışma saatleri, izinler, iş sağlığı ve güvenliği, sosyal güvenlik ve konut hakkı üzerinden değerlendirilmektedir.

\section{1. İş Bulma, Sözleșme Yapma ve İșten Ayrılma Süreci}

Araştırmanın yapıldığı yörede iş bulma, sözleşme yapma ve işten ayrılma kanunlardan bağımsız gelişmektedir. Kısmen gelenekten etkilenmekle birlikte genelde kurallar yörenin işgücü piyasasına göre geliştirilip uygulanır.

Konut kapıcıları zorunlu olarak aktif isgücü tedbirleri kapsamında mesleki eğitimden (Zaim , 1997, s.71) yararlanmalarına karşın, yine tedbirler arasında yer alan İŞKUR'dan yararlanmadıkları görülmektedir.

Araştırma yöresinde gerçekleşen iş sözleşmeleri temel mantık bakımından iş kanunu ve borçlar kanunu ile benzerlik göstermektedir. İş sözleşmesinin unsurlarından olan iş, karşılık ve bağlılık (Demircioğlu ve Centel, 2016, s.66) bulunmaktadır. Ancak detaylar bakımından farklılıklar görülmektedir. İş sözleşmesinin sona erme sürecinde görülen fesih sürelerinin bir anlamı bulunmamaktadır. Bu sürelerin dikkate alındığı ile ilgili bilgi bulunamamıştır. İş sözleşmeleri iradi bakımdan genelde karşlıklı anlaşma neticesine göre 
sona ermektedir. İş sözleşmesinin sona ermesinin sonucunda ihbar tazminatı, kıdem tazminatı, çalışma belgesi ve ibraname (Güven ve Erkul, 2011) verildiği görülmemiştir.

Uygulamada, iş arayanlar arkadaşlarına, akrabalarına ve hemşerilerine iş aradıkları ile ilgili bilgi vermektedirler. Çoğu kez, çalışmakta olan konut kapıcısı başka bir konut kapıcısı arandığında haberi olmaktadır. Çalışan konut kapıcısı, işçi aranma haberini yakınlarına bildirmektedir (K1, K2, K3, K4, K5, K6, K7, K8, K9).

Konut kapıcılarının işe alımı oldukça dikkat istemektedir. Apartman yöneticileri ${ }^{3}$ konut kapıcılarını işe alırken genelde referans sistemini kullanmaktadırlar. Daha önce çalıştığı yere veya arkadaşlarına sorarak çalıştıracakları kişi hakkında bilgi almaktadırlar. Konut kapıcıları, hem aynı meslekte çalıştığı konut kapıcılarını hem de apartman yöneticilerini tanımaktadırlar. Hangi apartmanın konut kapıcısına ihtiyacı olduğunu ve kimin iş aradığını bilmektedirler. Bu yüzden apartman yöneticileri çoğu kez kapıcılar aracılığı ile kapıcı bulma yoluna gitmektedir (K10, K11).

İş için başvuru yapan işçinin sadakat ve liyakati hususunda en iyi bilgi genelde işçinin yaşamış olduğu çevreden elde edilmektedir. İnsanlara nerelisin diye sorulmasının asıl nedeni de budur. Memleketi öğrenilen iş̧̧inin, işveren için güven tesisinde ilk adımdır. İkinci adım ise başvuru yapan kişinin yakınlarını arayarak onlardan bilgi almasıdır. İş sözleşmesinin büyük kısmı, ikilinin bir araya gelmesinden önce gıyaben yapılmış olmaktadır. Kişi görüşmeye çağrılırsa iş sözleşmesinin olma ihtimalinin yüksek olduğu bilinir (K3, $\mathrm{K} 10,11, \mathrm{~K} 12)$.

Görüşme sonrasında, sözleşmeler sözlü olarak yapılmaktadır. Yazılı olarak sözleşme yapıldığına hiç rastlanmamıştır. Sözlü sözleşme içerisinde konut kapıcısının alacağı ücret, kapıcı dairesi tahsisi, yapacağı işler yer almaktadır (K1, K2, K9, K10, K11).

Sözlü sözleşmelere bağlı kalındığı görülmüştür. Yazılı sözleşmeden kaçınmalarının nedenlerinden birincisi, işçi çalıştırma maliyetinin yüksekliğidir. İkincisi, işçinin eline kuvvetli delil verilmesidir. Yöneticiler işçi çalıştırma ile ilgili mevzuatı bilmediklerinden bu imzanın onlara ne sorumluluk yüklediğinden haberdar değildir. Bilmedikleri sorumlulukları almak istememektedirler. Üçüncüsü, piyasada oluşan sözlü pratik kuralların daha uygulanabilir olmasıdır. Dördüncüsü ise, devlet işleri ile uğraşmak istememeleridir ( K10, K11).

\footnotetext{
3 Ağrı İlinde daire sahipliğinden daha çok apartman sahipliği ön plandadır. Apartman sahipliği tek kişi veya akraba birlikteliği șeklinde görülür. Apartmandaki dairelerin hepsinin mülkiyeti bir kişide ise genelde apartman yöneticisi o olmaktadır. Eğer apartmandaki daire sahipleri akrabalardan oluşuyorsa, genelde geleneğe göre sözü geçen kişiye yöneticilik verilir. Toplu Konut İdaresi apartmanlarında olduğu gibi, daire sahipleri arasında akraballk söz konusu değilse, apartman yöneticiliğini isteyenler arasından birisi apartman yöneticisi olarak seçilmektedir. Genelde apartman yöneticiliği istenilmeyen bir durumdur.
} 
Bazı durumlarda sözleşmeler, mevsime göre yapılmaktadır. Sadece kalorifer kazanının yakıldığı mevsimlerde konut kapıcıları çalıştırılır. Bu şekilde çalışan konut kapıcılarının sayısı azdır. Az katlı apartmanlarda, kalorifer kazanı ateşleme işi aile içinde birisi tarafından ifa edilir. Eğer aileden birisi bulunmaz ise, genelde dışarıdan bir konut kapıcısı ile mevsimlik kalorifer kazanı ateşleme sözleşmesi yapılır (K8, K9).

Konut kapıcıları genelde uzun süreli çalışır. Kolay, yüksek ücretli, evine yakın iş vb. sebeplerden dolayı işlerini değiștirebilirler. Az da olsa, iş ahlakına uygun olmayan davranışlardan ve yönetici ile arasındaki sorunlardan dolayı da işten ayrılabilirler Tarafların anlaşması ile iş sözleşmesi fesih edilebilir. Bu durumda belirli fesih tarihi verilir ve o tarihe genelde her iki taraf ta uygun davranır. Diğer yandan ani şekilde iş sözleşmesini fesh edenler de bulunmaktadır. Süre beklemeden hemen ișten ayrılmalar ve ișten kovulmalar söz konusudur.

Çalışanların iş güvencesi yok denecek kadar azdır. Ancak işten çıkarılan ya da çıkanlar, sosyal ağlar sayesinde işten çıkar çıkmaz başka bir yerde iş bulduğu belirtilmektedir. Çalıştıkları sürelerin ücretlerini alsalar da tazminat söz konusu olmamaktadır. Kolaylıkla işten çıkarılabilmektedir (K3, K4, K5, K9).

\section{2. Ücret Hakkı}

İktisat kitaplarında, üretim unsurlarından biri olan emeğin fiyatı şeklinde ele alınan ücretler iktisadi ve sosyal hayatta çeşitli tesirleri olan çok cepheli bir konudur. Ücret, çalışan insanların gelirini ve hayat seviyesini tayin eden bir unsur, sanayinin gelişmesine tesir eden mühim bir maliyet faktörüdür. Milli gelirin diğer gelir grupları arasındaki dağılış tarzı bakımından ücret, o toplumda sosyal adaletin tecelli nispetini gösteren çok kapsamlı bir mahiyet arz etmektedir (Zaim , 1997, s.195).

Konut kapıcılarının ücretin belirlenme usulünün götürü ücret yöntemi olduğu söylenebilir. Çünkü konut kapıcılığı işi zamana, verime ve yüzde usulü gibi ücret belirleme yöntemlerine uymamaktadır. Konut kapıcılarının ücreti, belirli bir işin yapılması karşıllı̆ında verilmektedir. İşin yoğun olduğu dönemlerde ek ücret verildiği görülmemiştir. Bazı durumlarda bahşiş aldıkları gözlemlenmiștir.

Konut kapıcılarının bazıları bir', bazıları iki, çoğu üç ve dört apartmandan sorumlu olarak çalışmaktadırlar. Üç ya da dört apartmanda görev yapanlar, asgari ücretin üzerinde ücret alabilmektedirler (K1, K2, K3, K4).

4 Tek apartmandan sorumlu olanlar, genelde kapıcılık işini ek iş olarak yapmaktadır. Bu kişiler genelde başka yerlerde ücretle çalışmaktadır. Çarşıda esnafın yanında çalıșan işçilerde bu durum sık görülmektedir. Aynı zamanda, okullarda ve hastanelerde güvenlik ve temizlik görevlisi olan birçok kişinin de benzer şekilde çalıştığı görülmüştür. 
Kalorifer kazanı ateşleme ve temizlik işlerini beraber yürüten konut kapıcıları, genelde apartmanın işleri göz önüne alınarak ücret anlaşması yapmaktadırlar. Apartman başına konut kapıcısı ücretleri 500 ile 1000 TL arasında değişmektedir. Bu değişikliğe, kalorifer kazanının boyutu ve apartmandaki daire sayısı büyük etki etmektedir. Ara ödemleri denilen elektrik, su, temizlik maddesi vb. dışında kapıcılar için ödenen daire başı aidat (ücret) 50 ile $120 \mathrm{TL}$ arasında değişmektedir. Özellikle çok katlı Toplu Konut İdaresi konutlarında bu ödemler düşükken az katlı binalarda ödemeler yüksek olmaktadır (K1, K2, K4, K5).

Sadece haftada bir temizlik yapanlar, haftalık olarak 40 ile 70 TL (aylık yaklaşık 150-200 TL ) arasında anlaşmaktadır. Çoğunlukla haftada bir temizlik şeklinde gerçekleşen çalışmanın ücreti aylık olarak ödenmektedir. Diğer yandan sadece kalorifer kazanı ateşleyiciliği yapanlar bina başına aylık 400$700 \mathrm{TL}$ arasında almaktadır (K8, K9).

Hesaplamalar neticesinde, kalorifer kazan ateşleyiciliği, çöp toplama ve bina temizliğini bir arada yapan kişilerin ortalama 3000 TL civarında aylık ücret aldıkları görülmüştür. Sadece temizlik yapanlar yaklaşı 1000 TL civarında almaktadırlar. Diğer yanda sadece kalorifer kazanı ateşleyenler ise 2000 TL civarında ücret alabilmektedirler (K1, K2, K3, K4, K5, K6, K7, K8, K9, K10, K11).

\subsection{Calıșma ve Dinlenme Süreleri}

İşçinin dinlenmesini ve diğer ihtiyaçlarına zaman ayırmasını sağlamak amacıyla, haftalık ve günlük çalışma süreleri kanun ile sınırlandırılmış ve kural olarak işçinin bu süreler üzerinde çalıştırılması yasaklanmıştır (Sümer, 2016, s. 134).

Konut Kapıcıları Yönetmeliğinin 7. maddesine göre; Çalışma süresi genel olarak haftalık 45 saattir. Bu süre çalışma biçimine göre sözleşme ile azaltılabilir. Ayrıca, İş Kanununun 63. maddesindeki süreyi aksatmamak koşuluyla yoğunlaştırılmış çalışma iliş̧isi de kurulabilir. Çalışma süresi, kapıcının işte geçirdiği zamandır. Kapıcı konutu tahsis edilmiş işyerinde çalışma biçimine göre günlük çalışma süresi en çok dörde bölünebilir. Ara dinlenmesi çalışma süresinden sayılmaz. Çalışma saatleri, yaz ve kış saat uygulamaları ve iklim şartları dikkate alınarak düzenlenebilir.

Konut kapıcılarının çalışma süresinin toplamda haftalık 45 saati geçtiği görülmemiştir. Ancak genelde gece gerekli olan 11 saatlik dinlenme zamanına uygun olduğu söylenemez. Çünkü gece geç saatlerde (23.00-24.00 saatleri arasında) kalorifer kazanları kontrol edilmekte ve gerekli görülürse müdahale edilmektedir. Sabah erkenden (05.00-07.00 saatleri arasında) kalorifer kazanları ateşlendiği için gece dinlenme süresine uygun olmayan bir durum söz konusu olabilmektedir (K1, K2, K3, K4, K5, K6, K7, K9, K10, K11). 
Konut kapıcılarının en yoğun olduğu çalışma saatleri sabah 05.00-07.00 ve akşam 16.00-19.00 saatleri arasındadır. Kazanları kontrol ve müdahale etme saatleri ise 10.00-11.00 ve 23.00-24.00 saatleri arasındadır. Çöp toplama işlerini ise bazen kontrol saatlerinde bazen de ateşleme işlemlerinin öncesinde ya da sonrasinda yapabilmektedirler (K1, K2, K3, K4, K5, K6, K7, K9, K10, K11).

Konut Kapıclları Yönetmeliği'nin 9. maddesine göre; “İş Kanunu ile sözleşme hükümlerine göre hafta tatili verilir." denilmektedir. Araştırmaya konu olan konut kapıcıları, hafta tatillerini kış aylarında kullanamamaktadır. Ancak yaz aylarında gerekli hafta tatillerini fazlasıyla yaptıkları söylenebilir.

Sağlık durumlarındaki kötüleşme, yakınlarının cenazesi, evlenme, düğün vb. zamanlarda izin almada sorunları bulunmamaktadır. Çünkü ailenin diğer üyeleri konut kapıcılarına işlerinde yardım etmektedir. Çok nadir olarak görülse de meslektaşlarından yardım alabilmektedirler. Bu tür izinlere, yönetici genelde olumlu yanıt vermektedir. Hatta bu durumlarda, yöneticilerin konut kapıcılarına ateşleme ve temizleme işlerinde yardım ettikleri de görülmüștür (K1, K2, K3, K4, K5, K6, K7, K9, K10, K11).

Konut Kapıcıları Yönetmeliği'nin 10. maddesine göre; “2429 sayılı Ulusal Bayram ve Genel Tatiller Hakkında Kanunda yer alan tatil günlerinde, kapıcının çalıştırılıp çalıştırılamayacağı iş veya toplu iş sözleşmelerinde belirlenir. Bu günlere ilişsin ücretler, İş Kanunu'nun 47. maddesine uygun olarak ödenir."

Konut kapıcılarının bayram tatillerinden yalnızca dini bayram tatillerini kullandıkları görülmüştür. Eğer yaz mevsiminde olursa bayram tatilinde sorun teşkil edecek bir durum bulunmaz. Çünkü temizlik işleri haftada bir yapılmaktadır. Diğer yandan dairelerde yaşayanlar genelde bayram tatillerinde memleketlerine gittiklerinden (araştırmanın yapıldığı yörede genelde bayram tatilleri köylerde geçirilir) çöp toplama işi olmaz. Şayet bayram tatili döneminde, biriken çöp olursa, genelde evde yaşayanlar çöp konteynırına taşımaktadır. Konut kapıcılarının bayram tatilleri uzun süreli olmamaktadır. İki ya da üç gün bayram izni kullanırlar. Birçok konut kapıcısı bayram günlerinde de işinin başında bulunduğu görülmüştür. Bayramlar kış döneminde olursa bayram izni kullanabilmek için ailesindeki diğer üyelerden, arkadaşlarından ya da yöneticilerden yardım istemektedirler (K1, K4, K5, K7, K10, K11).

Konut Kapıcıları Yönetmeliği'nin 11. maddesine göre; “Kapıcıya İş Kanunu hükümlerine göre yıllık ücretli izin kullandırılır." Konut kapıcıları yıllık izinlerini bir seferde kullanamasalar da genelde yaz aylarında kullandıkları söylenebilir. Ancak bu izni bilinçli şekilde değil gerekli görüldükçe yöneticiden aldıkları izinlerle yapmaktadırlar. Yönetici yaz aylarında haftalık apartman temizliğini ve çöpün taşınmasını istemektedir. Bunun dışındaki zamanlarına müdahale etmemektedir. Durum böyle olunca izin kullanmak kolaylaşmaktadır. 


\subsection{Konut Hakkı}

Barınma, sosyal problemler ve sosyal politika ile ilgili tartışmalarda önemli bir rol oynamaktadır. Zenginlik yoksulluk, statü, ayrımcılık, sosyal dışlanma ve toplumsal bütünleşme kavramları, kişilerin nerede yaşadıkları ve barındıkları ile ilintilidir. Konut politikalarda çok önemli görülen konulardan birisi de yetersiz konutlarda barınma meselesidir (Murie, 2011, s. 452,456). Araştırma yöresinde, konut kapıcısı olarak çalışanların birçoğu yetersiz konutlarda barınmaktadır. Çalıştığı apartmanda konut tahsisi yapılanlar konut ihtiyacı bakımından birçok gereksinimlerinin karşılandığından bahsedilebilir.

Konut Kapıcıları Yönetmeliği'nin 13. maddesine göre; “Kapıcıya görevi nedeniyle konut verilmesi zorunlu değildir. Kapıcıya görevi nedeniyle konut verilmişse, konutun 3194 sayll İmar Kanunu ve Belediye İmar Yönetmelikleri ile öngörülen asgari koşullara uygun olması gerekir. Kapıcıya, görevi nedeniyle verilmiş olan konut için iş sözleşmesinin devamı süresince kira istenemez. Kapıcının su, elektrik, ısınma ve sıcak su giderlerine kısmen ya da tamamen katılıp katılmayacağı sözleşme ile belirlenir. Kapıcı konutunun boşaltılmasında, 634 sayılı Kat Mülkiyeti Kanununun Ek 2. maddesi hükümleri uygulanır. Bu konuda iş veya toplu iş sözleşmesinden doğan haklar saklıdır."

Ağrı ilinde çalışan konut kapıcılarının çoğunun kapıcı konutu bulunmamaktadır. Kapıcı konutları genelde apartmanın en alt katında bulunur. Bu konut, araba garajının ya da deponun yanında yer alır. Bodrum katı da denilmektedir. Kapıcı konutu olanlar kira giderinin yanı sıra birçok giderden muaf olabilmektedir. Isınma, elektrik, su vb. giderlerden ya tamamen ya da kısmen ayrı tutulabilmektedirler. Böylece kapıcı olarak çalışanlar daha müreffeh bir hayat yaşamış olmaktadır. Bunların yanı sıra, kapıcı konutunda yaşayan konut kapıcıları apartmanda ikamet edenlerin ayni yardımlarını daha kolay alabilmektedirler (K2, K3, K7).

Konut kapıcısı dairesinde ikamet edenler, yalıtım sistemi ve toplu ısınmadan dolayı ısınma sorunu çekmemektedir. Isınma giderini kendisi karşılamadığı ya da kısmen karşıladığı için düşük maliyetle ısınmış olmaktadır. Araştırmanın yapıldığı yörede ısınma maliyeti oldukça yüksektir. ${ }^{5}$ Isınma, aidat ve kira giderlerinin olmamasından dolayı, aylık yaklaşık 1000 TL $^{6}$ kadar ek yardım aldıkları söylenebilir. Kapıcı dairesinde oturanların diğer önemli bir farklılığı evde banyo, tuvalet, mutfak vb. yerlerin daha kullanışlı ve estetik olmasıdır. Duvarların boyası, alt döşemesi, musluğu vb. malzemeleri daha kalitelidir ve insanın müreffeh yașamasında önemli etkiye sahiptir.

Apartman dairelerde oturanlar, eşya değiştirirken ikinci ele satmak yerine kapıcılara vermeyi tercih etmektedir. Bu sayede konut kapıcıları birçok

5 Kalorifer kazanın ısıtmada yüksek kaliteli kömür kullanılmaktadır. Daire başı kömür tüketimi yaklaşık 2 ile 3 ton arasındadır. 2019 yılı Sonbahar Döneminde kalorifer kazanında yakılan kömürün tonu 1350 TL civarindadır.

6 Aylık Isınma maliyeti=1350*2.5 $\backslash 12=281.25 ; 281.25($ Isinma $)+80($ aidat $)+600($ kira $)=961.25$ 
eşyaya sahip olmaktadır. Kendi eşyalarını sürekli iyileştirirken kendi eskilerini de akrabalarına vermektedir. Böylece konut kapıcıları bir tarafıyla kendi refah düzeylerini artırırken diğer yanıyla akrabalarına da fayda sağlamış olmaktadır (K2, K3, K7, K10, K11).

\subsection{Sosyal Güvenlik ve İş Güvenliği}

Sosyal güvenliğin kapsamı içerisinde genelde iş kazası, meslek hastalığı, hastalık, analık halleri, işsizlik durumu, malullük, yaşlılık, ölüm sigortası, sosyal yardım, sosyal hizmet vb. görülmektedir (Gerek \& Oral, 2011, s. 91,144,171). Bu kollardan sosyal yardım ve sosyal hizmet dışındakilerden genelde prim karşılığında yararlanılabilmektedir. Ağrı ilinde konut kapıcılarının çoğu kayıtsız çalıştığından ancak yoksullura, engellilere, yaşlılara ve çocuklara sunulan sosyal yardım ve sosyal hizmetlerden faydalanabilmektedir.

Formel çalışma yaşamına giremeyip, enformel çalışma yaşamına dâhil olan kesimin sosyal güvenliğe dâhil edilmesinin yolunu açacak düzenlemelerin (Kesgin, 2011, s. 72) artırılmasına ihtiyaç bulunmaktadır. Ağrı ilinde kamu kurum ve kuruluşları dışında çalışan konut kapıcılarının en önemli sorununu sosyal güvenlik alanı olușturmaktadır. Kısa ve uzun dönemli sosyal risklere karşı sigortaları bulunmamaktadır. Sigorta pirimi işveren tarafından ödenen bir kişi (Katılımcı2) bulunmaktadır. Bir kişi de (Katılımcı3) kendi sigorta primini ödemektedir. Sosyal güvenlik kurumuna çoğu kişi kayıt yaptırmasına karşın devamı söz konusu olmamaktadır. Emekli olma yaşları yaklaşınca sigortalı çalıştığı günlerini toplatıp, kalan günlerin primlerini toplu ödeyerek emekli olmayı düşünmektedirler (K1, K2, K3, K4, K5, K6, K7, K8, K9).

Kalorifer kazanı ateşleyicileri belge olmadan çalışamamaktadır. Belgelerini genelde Halk Eğitim Merkezi'nden alabilmektedirler. Belge alırken yakıt tasarrufu, güvenlik ve emniyet tedbirleri vb. konularda bilgiler verilmektedir. Genç çalışanlar iş sağlığı ve güvenliğine kısmen dikkat ederken orta yaştaki çalışanlar birçok aşamada sağlıklarına dikkat etmektedirler. Bazı kapıcıların iş yaparken maske ve eldiven taktıkları bazılarının da kömürü ve külü sulayıp sonra işlemlere başladıkları gözlemlenmiștir (K1, K2, K3, K4, K5, K6, K7, K9).

\subsection{Kapıcların Ek Menfaat Elde Etme Yöntemleri}

Bazı konut kapıcıları işi önceleyip sürekli işi ile ilgilenirken bazı konut kapıcıları ikili ilişkilere önem verip işten çok kendi kazançları ile ilgilenmektedir

7 İşine önem veren konut kapıcıları kalorifer kazanı ateşleme işinde ustalaşmıştır. Kalorifer kazanının ateşlenmesi hususunda ince detayları bilmektedir. Işsini layıkıyla yapması, dairede oturanlara olumlu yönde yansımaktadır. Kalorifer kazanının ilk ateşlemesini az kömürle başlatıp sonrasında azar azar takviyeler yaparak oda sıcaklıklarını sürekli aynı tutmaktadır. Kendisini önemseyen ve işe gereken önemi vermeyen konut kapıcıları ateşlenme sırasında çok kömür kullanarak aşırı sıcaklık sonrası tekrar çabuk soğumaya 
Kendi işlerini başkalarına yaptırıp, ek kazanç sağlama yönünde çaba sarf etmektedirler. Konut kapıcıları ek gelir elde etmek için genelde kiralık ve satılık ev bulmaya aracılık yapıp komisyon ücreti almaktadır. Kurye işlerinden de önemli miktarda gelir elde etmektedirler. Aynı zamanda, işlerinde atık kömür toplayıcılarını çalıştırıp yarar sağlamaktadırlar (K1, K2, K3, K4, K5, K6, K7).

Konut kapıcıları, kiralık ve satılık konut arayanlardan belli miktarlarda komisyon ücreti alıp boşalan ve satılan daireleri haber vermektedir. Özellikle gözde yerlerde ev kiralamak ve satın almak isteyen kişiler, konut kapıcılarına belirli miktarlarda komisyon ücreti vererek onlardan haber almada ve aracı olmada faydalanmaktadır (K1, K2, K3, K4, K5, K6, K7).

Konut kapıcıları, atık kömür toplayıcılarının ${ }^{8}$ rekabetinden yararlanarak onları kendi işlerinde karşılıksız çalıştırmaktadır. Konut kapıcıları, kalorifer

neden olmaktadır. Evin sıcaklığı bir anda çok artmakta ve sonrasında hızla düşmektedir. Bir taraftan evin sıcaklığının ayarlanmaması diğer yandan da çok kömür yanmasından dolayı verimlilik düşmektedir.

Birisi sürekli işini takip ederken diğeri ise işini aceleyle yapıp gitmektedir. iki binanın karşılaştırması sonucunda işini layıkıyla yapan A kişisi B kişisine gör daire başı 900 kilogram tasarruf etmiştir. Aynı zamanda dairede oturanlar sıcaklık seviyesinden memnun kalmıştır. Ama işine ehemmiyet vererek yapan kişinin, çalışma hayatı diğerine göre daha inişli çıkışlıdır. Yöneticilerle ilişkileri B kişisinde daha olumlu iken, A kişisinde olumsuz durumdadır $(K 1, K 3)$.

8 Atık toplayıcıları mevsimine göre farklı işler yapmaktadır. Kış aylarında, kömür küllerini eleyerek tam yanmamış kömürleri ayırt edilmektedirler. Sonra bu kömürleri satarak kazanç sağlamaktadırlar. Yılda yaklaşık beş-altı ay boyunca bu işi yaptıkları görülmektedir. Kömür tüketiminin en çok arttığı Aralık, Ocak ve Şubat ayları onlar için kazançlı aylar sayılmaktadır (K12, K13, K14).

Atık kömür toplayıcıları sabah beşte işe gitmek için yola çıkmaktadır ve konut kapıcılarının çöpe götürdüğü külleri tek tek kontrol etmektedir. Elenmemiş külleri tespit edip elemektedirler. Çıkarılan yanmamış kömürler çuvallara doldurulmaktadır. Çuvalları genelde apartmanlardaki kömür çuvallarından oluşmaktadır. Kırk veya yirmi beş kiloluk çuvalların yarısından yukarısına kadar doldurulmaktadır. Taşımasını dört tekerli tezgâh arabaları veya at arabaları ile yapmaktadırlar. Tezgâh arabaları daha sık kullanılmaktadır. Beşte başlayan mesai saat dokuza kadar devam etmektedir. Toplanan kömürleri kendi evlerinde kullandıkları nadir görülmektedir. Kömürler satılmak için toplanmaktadır. Bu kömürlerin müşterileri en çok kahvehaneler ve sanayide işyeri sahibi esnaflardır.

Kalorifer kazanları genelde iki ile dört günde bir temizlenir. Büyük kazanlar dört günde bir temizlenirken küçükleri genelde iki günde bir temizlenir. Kazan temizleme işleri kapıcıların görevlerindendir. Ancak atık kömür toplayıcıları, kömür atığı dolu külü rakibinin almaması için kalorifer kazanlarını temizlemektedir ( K12, K13, K14).

Atık kömür toplayıcılarının en çok istediği durum elektriklerin uzun süreli kesilmesidir. Uzun süre kesilen elektrik neticesinde kömürler yanmadan çıkarılmaktadır. Tekrar yakılması güç olduğu için genelde kül niyetine çöpe atılmaktadır. Kül içerisindeki kömür oranının yüksek olması en çok istenilen durumdur. Hem elemesi kolay hem hasılatın çok olması anlamına gelmektedir. Ağrı ilinde yılda birkaç kez uzun süreli elektrik kesintisi olmaktadır. Bu durum atık kömür toplayıcılarını oldukça memnun etmektedir (K12, K13, K14).

Kışın atık kömür toplayıcılığını yapanlar, diğer zamanlarında buldukları işleri yapmaktadır. Bu işler arasında meyve sebze satımı, çeşitli taşıma işleri, gündelikçi çalışma, inşaat işleri vb. bulunmaktadır. Genelde serbest çalışmaktadırlar. Her hangi bir meslek içerisinde değerlendirilemezler (K12, K13, K14). 
kazanından kül temizleme işini atık kömür toplayıcılarına yaptırmaktadırlar. Atık kömür toplayıcıları da daha fazla atık kömür elde ettikleri için bu durumdan fayda sağlamaktadır.

\section{Sonuç}

Ağrı ili Merkez ilçesinde yapılan çalışma neticesinde, konut kapıcılarının çoğunun kırdan kente göç ederek konut kapıcıllğı işine girdikleri görülmüştür. $\mathrm{Bu}$ ișe girebilmeleri onların kentte tutunabilmelerini sağlamaktadır.

Konut kapıcılı̆̆ı yapanların çoğunun eğitim durumlarının okuryazar, ilkokul ve ortaokul olduğu görülmüştür. Konut kapıcılarının neredeyse hepsinin evli olduğu tespit edilmiştir. Ayrıca konut kapıcılığı işi için evlilerin tercih edildiği bilinmektedir. Yaș aralıkları 30-50 arasında yoğunlașmaktadır.

Konut kapıcılar daha iyi iş bulmaları durumunda, konut kapıcılığından farklı bir mesleğe yönelebileceği söylenebilir. Çoğu konut kapıcısı, ücret bakımından yüksek ve çalışma şartları bakımından daha konforlu bir iş bulmasa da çocuklarının daha kaliteli bir eğitim alma olanağı, onları tatmin etmektedir.

Konut kapıcılarının aldıkları ücret düşük olsa da genelde asgari ücretin üzerinde ücret aldıkları görülmektedir. Özellikle üç ve üzeri apartmanın kapıcılığını yapanların gelir durumlarının daha yüksek olduğu görülmektedir. Apartman aidatlarından oluşan gelirlerine, ek gelirler de eklenince öncesinde yaşamış olduğu köy hayatındaki durumundan daha müreffeh bir yaşam sürdüğü söylenebilir.

Çalışma saatleri bakımından sorunlarının olduğu görülmemiștir. Ama gece dinlenmesi bakımından sorun teșkil eden durumlar görülmüștür. Özellikle kış mevsiminin kendini yoğun hissettirdiği Aralık, Ocak ve Şubat aylarında gece genelde 22:00-24:00 arasında kalorifer kazanların kontrolü ve yakıt takviyesi işi yapılmaktadır. Sabah ise genelde 05:00-07:00 saatleri arasında yoğun çalışma görülmektedir. Bu süre İş Kanunun gece dinlenmesi için uygun gördüğü 11 saatlik süreden oldukça azdır. Yılın tümünü düşünerek hesaplama yapılırsa çalışma saatlerinin haftalık 45 saatin altında seyrettiği görülmektedir. Diğer yandan işin yoğun olduğu zamanlarda hafta tatili kullanmadıkları görülmüştür.

Kapıcı konutunda kalanların kalmayanlara göre daha müreffeh hayat yaşadıkları söylenebilir. Özellikle kira giderinin olmamasının yanı sıra ısınma giderlerinin de apartman sakinleri tarafından karşılanması, konut kapıcısının yaşama şartlarını oldukça iyileștirmektedir. Kapıcı konutunda kalanların

Konut kapıcıları ile atık kömür toplayanlar arasında karşılıklı menfaatin ilerisine taşınan durumlar da söz konusudur. Konut kapıcıları kömürleri yanmış gibi gösterip ucuz fiyattan atık kömür toplayıcısına sattığı tespit edilmiştir. Bunun yanı sıra, konut kapıcıları dışarıdan gelen insanları zarara uğratmak, zenginden alıp fakire vermek gibi nedenlerle de tam yanmamış kömürleri atık kömür toplayıcılarına vermektedir. 
apartman sakinlerinin ikinci el eşyalarını kendilerinin kullandıkları bazen de akraba ve arkadaşlarına verdikleri görülmüştür.

Sosyal güvenliğin kapsamı içerisinde yer alan iş kazası, meslek hastalığı, hastalık, analık halleri, işsizlik durumu, malullük, yaşlılık, ölüm sigortası vb. yardım ve hizmetlerden konut kapıcıların çoğu kayıtsız çalıştıkları için yararlanamamaktadır.

Konut kapıcılarının atık kömür toplayıcılarını çalıştırarak işlerin bir kısmını karşılık ödemeden başkalarına yaptırdıkları tespit edilmiştir. Aynı zamanda ev kiralamak ve satın almak isteyenlere aracılık yaparak komisyon aldıkları ve kurye işleri yaparak ek gelir elde ettiklerine rastlanmıştır.

Konut kapıcılarının yanı sıra onlarla ilişkili olduğu için kısmen araştırılan atık kömür toplayıcıların durumu her bakımdan çok zordur. Temel gereksinim maddeleri olan gıda, barınma ve giyim konusunda büyük sıkıntıları bulunmaktadır. Barınma yerleri gecekondu yapısıdır. Giyimleri çöplerden ya da başkalarının ikinci el eşyalarından oluşmaktadır. Gıda ise günlük çalışmaları neticesinde kazandıkları ve çöplerden topladıkları ile sınırlıdır. Atık kömür toplayıcısı olarak çalışanların geneli çocuk yaştadır.

Araştırma süreci içerisinde çok katlı binaların sayısı gözle görülür şekilde artarken aynı zamanda doğalgazın ısıtmada kullanılması sonucu konut kapıcllığının görevleri de değişmektedir. Yeni dönemde, temizlik ve güvenlik işleri ön plana çıkmaktadır. Site biçiminde olan konutlar, güvenlik (bekçilik) ve temizlik işçisi çalıştırırken tek apartmanlar genelde temizlik işçisi çalıştırmakta ve güvenliği kameralar ile sağlamaktadır.

\section{KAYNAKÇA}

Bates, D. G. (2013). 21. yüzyılda kültürel antropoloji insanın doğadaki yeri. İstanbul: İstanbul Bilgi Üniversitesi Yayınları.

Demircioğlu, M., ve Centel, T. (2016). İs hukuku. İstanbul: Beta Yayıncılık.

Gerek, N., ve Oral, A. İ. (2011). Sosyal güvenlik hukuku. Eskişehir: Anadolu Üniversitesi.

Güven, E., ve Erkul, İ. (2011). İş hukuku. Eskişehir: Anadolu Üniversitesi Yayınları.

Kesgin, B. (2011). Çalışma yaşamında değişen yoksulluk: Çalışan yoksullar. İş Ahlakı Dergisi, 4(1), 65-75.

Kılıç, N. Ö., ve Beşer, M. (2018). Gelir dağılımı ve yoksulluk kavramlarının Ağrı ili özelinde değerlendirilmesi. Ağrı ilinin sosyo-ekonomik profili (s. 141152). içinde Ankara: AİÇÜ Yayınları.

Murie, A. (2011). Konut politikası. P. Alcock, M. May, \& K. Rowlingson içinde, Sosyal politika (s. 452-460). Ankara: Siyasal Kitapevi.

Okay, S. (1979). Türk iş hukuku açısından konut kapıcıları ve kapıcılık hizmeti. Sosyal Siyaset Konferansları Dergisi, 30, 40-56.

Suğur, N., Suğur, S., ve Şavran, T. G. (2008). Türkiye'de orta sınıfın mazbut hizmetkârları: Kapıcılar, gündelikçiler ve çocuk bakıcıları. Ankara Üniversitesi SBF Dergisi, 63(3), 161-183.

Sümer, H. H. (2016). İ̧̧ hukuku. Ankara: Seçkin Yayıncllık. 
Şahin, H. (2019). Cumhuriyet döneminde geleneksel köy yaşamında insan çalıştırma biçimleri: Erzurum Oltu ilçesi köy örneği. Jornal of Oral History, 2(1), 1-13.

Turan, E., Altaban Karabey, Ş., Sarıtaş, E. C., ve Altınsoy, S. (2018). On birinci kalkınma planı konut politikaları. Ankara: Kalkınma Bakanlığı.

Uğurlu, S., ve Genç, M. (2018). Ağrı ilinin nüfus ve demokrafik yapısının incelenmesi. K. Karabulut içinde, Ağrı ilinin sosyo-ekonomik profili (s. 299-312). Ankara: Ai̇çÜ Yayınları.

Ünal , M. A. (2019). Osmanlı müesseleri tarihi (13. Baskı). Isparta: Fakülte Kitapevi Yayınları.

Yola, U. (2017). Konut kapıcılarının 4857 sayılı iş kanunu'ndan doğan haklarının değerlendirilmesi. Mali Çözüm Dergisi, Mart-Nisan, 119-126.

Zaim , S. (1997). Çalıșma ekonomisi. İstanbul: Filiz Kitapevi.

4857 Sayılı İş Kanunu (10.06.2003). Resmi Gazete (Sayı: 25134).

Çalışma Süreleri Yönetmeliği (06.04.2004). Resmi Gazete (Sayı: 25425).

Konut Kapıcı Yönetmeliği (03.03.2004). Resmi Gazete ( Sayı: 25391).

3194 Sayılı İmar Kanunu (03.05.1985). Resmi Gazete (Sayı: 18749).

634 Sayılı Kat Mülkiyeti Kanunu (23.06.1965). Resmi Gazete ( Sayı: 12038). 